\title{
Interaction between a mobile and a sessile species in SW Atlantic mudflats: Lack of negative effects of the mud crab Cyrtograpsus angulatus Dana, 1851 on filtration rate and growth of the infaunal clam Tagelus plebeius (Lightfoot, 1786)
}

\author{
Mariana Addino *,1, María F. Alvarez ${ }^{2}$, Oscar Iribarne, Betina J. Lomovasky \\ Instituto de Investigaciones Marinas y Costeras (IIMyC), CONICET-UNMDP, FCEyN, Laboratorio de Ecología, Argentina
}

\section{A R T I C L E I N F O}

\section{Article history:}

Received 23 February 2015

Received in revised form 10 December 2015

Accepted 11 December 2015

Available online 24 December 2015

\section{Keywords:}

Biogenic habitat modifications

Cyrtograpsus angulatus

Tagelus plebeius

Filtration rate

Growth

\begin{abstract}
A B S T R A C T
Biogenic modifications of benthic environment by organism's activities like feeding, burrowing or excretion have in general negative implications for cohabiting sessile infauna, especially for suspension-feeders. However, the outcome of these interactions depends on several biological and physical characteristics and thus, it is not easily predictable in soft bottom environments. The stout razor clam Tagelus plebeius, an estuarine, infaunal and sessile filter feeder species, coexists in Mar Chiquita coastal lagoon (Argentina, $37^{\circ} 32^{\prime} \mathrm{S}, 57^{\circ} 19^{\prime} \mathrm{W}$ ) with the mud crab Cyrtograpsus angulatus, a very mobile benthic consumer. Due to the intense crab activity and consequent habitat transformation, we predicted negative effects on clams' filtration rate and their growth. However, an inclusion experiment showed that $T$. plebeius filtration rate was higher in enclosures when crabs were present responding to enhanced turbidity and chlorophyll $a$. Additionally, another experiment showed that mean condition index as well as mean shell growth increment of clams was not negatively affected by crabs, although maximum values of shell growth increments $(\mathrm{mm})$ were smaller in crab inclusions. Our findings suggest that the clams can exploit the increased food availability (i.e., $\mathrm{Chl} a$ ) generated by resuspension and are also not affected by the disturbance that crabs can make over sediment surface. In conclusion, contrary to the generalized outcome proposed for this kind of interaction, crabs do not have a negative effect on T. plebeius.
\end{abstract}

(c) 2015 Elsevier B.V. All rights reserved.

\section{Introduction}

Benthic species assemblage and interactions are frequently modified by the mobility of the organisms and habitat biogenic transformations (Murray et al., 2002). Through feeding, excretion, burrowing and bioconstruction, macrofauna influences superficial particle transport (Rosenberg, 2001), changes sediment composition and stability (Widdows and Brinsley, 2002), and changes the flux of particles (Boudreau, 1997) and solutes (Michaud et al., 2006) between the sediment and the overlaying water (i.e. sediment-water interface). Sessile infauna is especially affected by these changes in the physical environment. For example, changes in physical characteristics of sedimentwater interface generated by biotic processes affect filtration activity

\footnotetext{
* Corresponding author at: Rodriguez Peña 4046, IIMyC, Casilla de Correo 1245, Mar del Plata 7600, Argentina.

E-mail addresses: maddino@mdp.edu.ar (M. Addino),feralvarez@ilpla.edu.ar

(M.F. Alvarez), osiriba@mdp.edu.ar (O. Iribarne), lomovask@mdp.edu.ar (B.J. Lomovasky).

1 Present address: Instituto de Investigaciones Marinas y Costeras (IIMyC), CONICETUNMDP, FCEyN, Grupo de Ecología y Paleoecología de Ambientes Acuáticos Continentales, Argentina.

2 Present address: Laboratorio Cuenca del Salado, Instituto de Limnología “Dr. Raúl A. Ringuelet", (ILPLA, CONICET - UNLP), Argentina.
}

of benthic filter-feeding species (Pillay et al., 2007) since this interface provide their food supply (Herman et al., 1999). Generally, sediment disruption by animal activities (e.g. feeding, burrowing) is predicted to have negative effects on suspension-feeding infauna (Rhoads and Young, 1970; Wilson, 1991). Nonetheless, it depends on other factors such as sediment properties and/or characteristics and functional traits of interacting species (e.g. body size, frequency of disturbance; Posey, 1987; Snelgrove and Butman, 1994). For example, filtration rate of bivalves may respond positively to increased seston load (Jørgensen, 1996). However, extremely high seston concentrations may lead to clogging of filtration apparatus with negative consequences on growth and survival (Jørgensen, 1996; Ellis et al., 2002). Thus, the outcome of these interactions in soft-bottom sediments is not easily predictable.

The stout razor clam Tagelus plebeius is an estuarine, filter feeder species which is distributed along the American Atlantic coast, from Cape Cod ( $42^{\circ} \mathrm{N}$, Mass. USA; Leal, 2002) to the Northern Argentinean Patagonia ( $41^{\circ}$ S, Argentina; Scarabino, 1977) although this distribution is not continuous. This clam is often an important infaunal community component (e.g. Seitz et al., 2006) inhabiting permanent burrows (Gutiérrez and Iribarne, 2004) up to $70 \mathrm{~cm}$ depth in estuarine tidal flats with cohesive sandy silt sediments (Holland and Dean, 1977) and salinities ranging from 41 to 2\%o (Addino, 2014). The location of 
clams is visible by the presence of their siphon holes in the sediment surface (Gutiérrez and Iribarne, 2004) reaching densities of up to 120 ind $\mathrm{m}^{-2}$ in the low intertidal (Alvarez, 2013). Stable isotope analysis revealed that in the Southwest Atlantic estuaries suspended benthic microalgae and phytoplankton comprise its main food supply (Botto et al., 2005). In its southernmost distribution range T. plebeius coexists with the mud crab Cyrtograpsus angulatus $\left(41^{\circ} \mathrm{S}\right.$, Argentina to $27^{\circ} \mathrm{S}$, Brazil; Boschi, 1964) which is an omnivorous benthic consumer (Schwindt et al., 2001; Botto et al., 2005) that inhabits predominantly the lower intertidal and the adjacent subtidal level (Spivak et al., 1994). In estuaries, the adults of this species are found in soft-muddy bottoms characterized by high densities of detritivorous polychaetes mostly of the genus Heteromastus and Laeonereis (Spivak, 1997). In Mar Chiquita lagoon crabs predate these annelids (Olivier et al., 1972; Schwindt et al., 2001) and also consume pelagic and benthic microalgae, some meiofaunal organisms and plant debris (Schwindt et al., 2001), being also scavengers (Olivier et al., 1972). The adult crabs take shelter remaining superficially buried in the sediment (Spivak, 1997) up to $4 \mathrm{~cm}$ depth (Schwindt et al., 2001). In fact, Schwindt et al. (2001) reported sediment reworking by $C$. angulatus to a depth of $5 \mathrm{~cm}$ in some areas of the lagoon. Moreover, they suspend sediment through locomotion (pers. obs.). They also show large spatial displacement mainly related to tidal water movement, usually concentrating many crabs along the water edge (Boschi, 1964; Spivak et al., 1996). Due to this high mobility and great small-scale variability quantitative studies of its population dynamics are very difficult. However, rough estimates in Mar Chiquita coastal lagoon indicate that its density varies from clusters of thousands of crabs near the mouth to single individuals in the inner part of the lagoon (Spivak et al., 1994). Therefore, due to its feeding habits, superficial burrowing and displacement they could lead to disruption and resuspension of superficial sediments acting as a biodiffuser (see François et al., 2002) and thus modifying sediment-water interface with possible consequences for clam feeding.

Furthermore, it is known that in the SW Atlantic Mar Chiquita coastal lagoon $\left(37^{\circ} 32^{\prime} \mathrm{S}, 57^{\circ} 19^{\prime} \mathrm{W}\right.$, Argentina) other crab species (Neohelice (=Chasmagnatus) granulata) negatively affects growth and condition index of T. plebeius due to both, direct contact with consequent shell damage and indirect mechanisms probably related to behavioural changes in clams and their associated energy costs (Lomovasky et al., 2006). These effects are stronger in the lower intertidal and it is suggested that even the displacement of crabs over the sediment surface can lead those behavioural changes affecting energy budget of clams (Lomovasky et al., 2006). In this sense, considering that C. angulatus also wander over the sediment surface, it is probable that its activity over siphon holes (i.e. over the bottom) also disturbs clams. Thus, we expect changes in the clam's behaviour such as escape responses or lower feeding activity with consequences on the clam's energy budget and growth. In this context, the aims of this study were to evaluate if 1 ) the crab C. angulatus modify particle load in the sediment-water interface and thus, filtration activity of the razor clam T. plebeius and 2) if crab presence affects shell and somatic growth of clams.

\section{Materials and methods}

\subsection{Study site}

Samplings and field experiments were made in Mar Chiquita coastal lagoon in an area called CELPA located approximately $2.5 \mathrm{~km}$ from the lagoon inlet (Fig. 1$)$, at the low intertidal level $(0.40 \mathrm{~m}$ above mean low tide, following Lomovasky et al., 2006) where sediment mean grain size is $115 \mu \mathrm{m}(\mathrm{SD}=9.55$, range $=103.57-131.75)$ and mean turbidity is 3.06 NTU $(0.84$, range $=1.55-4.44)$ (Addino, unpublished data). The lagoon is a brackish water area of $46 \mathrm{~km}^{2}$ permanently connected to the sea (Isla, 1997). The entrance channel is approximately $6 \mathrm{~km}$ long, $200 \mathrm{~m}$ width and its depth is between 1.5 and $2 \mathrm{~m}$ (Fasano et al., 1982; Reta et al., 2001). It is characterized by small tidal amplitudes (up to $1 \mathrm{~m}$, Isla, 1997) which are mainly generated by the winds and rain (Isla and Garrido, 2001).

\subsection{Displacement of $C$. angulatus in the tidal flat}

To corroborate the pattern of crab displacement with tidal water movement (see Introduction), field observations were made in spring 2009. Fifty eight fixed points were randomly stated (marked with a fine wire stake protruding a few centimetres from the sediment) in the tidal flat. Then the number of crabs that cross through a $10 \mathrm{~cm}$ diameter area around each point during 10 min was observed. During the observations, we could see that the use of the marks did not modify the behaviour of crabs (i.e. crabs did not stay around the stakes). Observations were made over a mudflat extent of approximately $500 \mathrm{~m}$ in three states of the tidal cycle defined as: stable high tide, flooding and ebbing. Observations were made simultaneously by 3 observers which could see 2 points at the same time, thus the observation periods were conducted for no more than $1 \mathrm{~h}$ and $40 \mathrm{~min}$ at a time. The null hypothesis of no difference in mean crabs $\mathrm{h}^{-1}$ crossing around a fixed point between tidal moments was tested by ANOVA. Data were square-root transformed to fulfil the analysis assumptions (Zar, 1999).

\subsection{Effect of C. angulatus on suspended material and filtration activity of T. plebeius}

To evaluate 1 ) if $C$. angulatus changes the particle load and clam's food availability in the sediment-water interface and 2) the effect on clam's filtration rate (FR), an inclusion/exclusion field experiment was carried out in spring 2009. Thirty two plastic cylinders $(20 \mathrm{~cm}$ height, $18 \mathrm{~cm}$ diameter) were established in the mudflat where they were flooded every high tide. Cylinders were buried $10 \mathrm{~cm}$ into the sediment to ensure no exchange of water during sampling procedure in ebbing tide. The volume into the containers (delimited by cylinder walls and sediment surface) was 2.51 . Each of 16 cylinders contained one clam which was already buried there since their siphon holes were visible in the sediment surface. The remaining 16 containers were established above sediment without clams. After 7 days of acclimation we were able to use 14 with clam and 11 without, the other containers were lost by storms or discarded because of the intrusion of crabs. Water samples from the sediment-water interface were taken in the following way: just after the tide ebbed when the containers were uncovered but full of water (time 0 ) the first sample was taken by carefully submerging a $3 \mathrm{ml}$ plastic tube. This procedure was made the more closely possible to the sediment surface but carefully enough to avoid sediment removal. Also, we ensure that the procedure was exactly the same in all treatments; hence any difference found is due to the treatment itself. Immediately after, $1 \mathrm{crab}(\approx 3 \mathrm{~cm}$ carapace) was added into each of 14 containers, 7 with clam and 7 without clam. Thus, we completed 4 treatments: only clam (Clam, $\mathrm{n}=7$ ), clam and crab (Clam-Crab, $\mathrm{n}=$ 7), only crab (Crab, $n=7$ ) and control (without clam and crab, Control, $\mathrm{n}=4$ ). Thereafter, a water sample ( $3 \mathrm{ml}$ ) was taken from each container every $10 \mathrm{~min}$ in a total period of $40 \mathrm{~min}$ (five samples in total). Immediately after water samples were taken turbidity (NTU) and Chl $a$ $\left(\mu \mathrm{g} \mathrm{l}^{-1}\right.$ ) were measured in the field with an Aquafluor handheld Fluorometer (Turner Design, Model 8000-01, detection range: Turbidity = 0.5-150 NTU, Chl $a=0.05-300 \mu \mathrm{g} \mathrm{l}^{-1}$ ) following Bruschetti et al. (2008).Turbidity was used as representative of particle load in the sediment-water interface (Ellis et al., 2002) and Chl $a$ as food availability. To evaluate the effect of crab on sediment-water interface we compared water turbidity and Chl $a$ between treatments Crab and Control at the beginning (time 0 ) and at the end of the experimental time (at $40 \mathrm{~min}$ ) by $\mathrm{t}_{\mathrm{c}}$-test (corrected t-test, Welch approximation, Zar, 1999). As well as evaluating if crabs affect FR of clams, we compared FR (see calculation details below) between treatments Clam and Clam-Crab in each time interval of $10 \mathrm{~min}$ by $\mathrm{t}_{\mathrm{c}}$-test. Before this final test (at the end of the experiment) clams were extracted and their length $(\mathrm{L}$, 


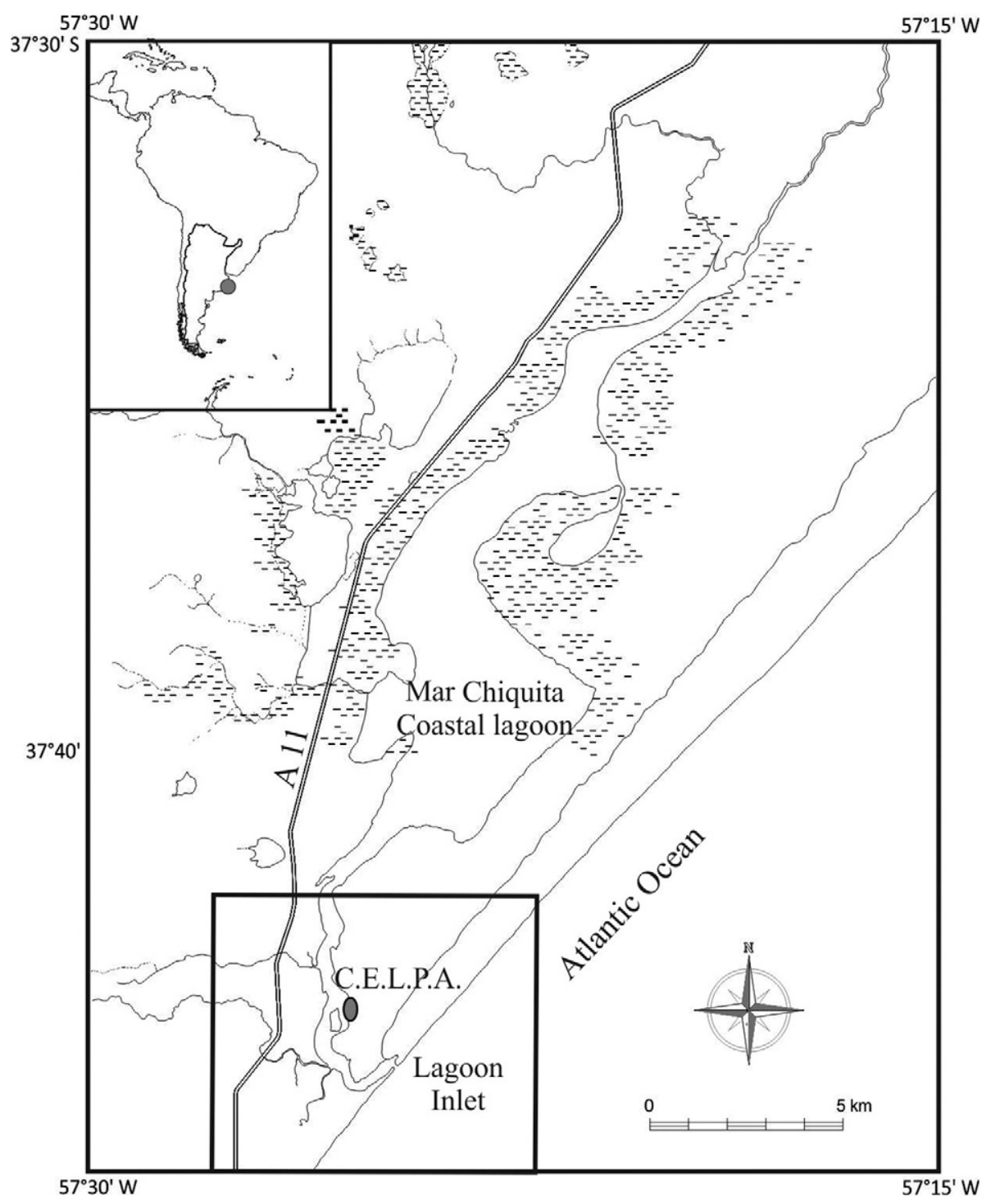

Fig. 1. Study site.

anterior-posterior axis; precision $\pm 0.01 \mathrm{~mm}$ ) was measured to compare mean $\mathrm{L}$ between treatments and to analyse the relationship between L and FR by simple regressions (Zar, 1999) to dismiss the effect of clam's size on FR (see Section 3.2).

The FR $\left(\mathrm{h}^{-1}\right)$ of clams was calculated with the indirect method (following Cohen et al., 1984) which measures the rate of exponential decay of particle concentration in a time interval:

$\mathrm{FR}=\mathrm{Vi} \times \frac{\left(\ln \left(\frac{\operatorname{Tur}_{\mathrm{b}}}{\operatorname{Tur}_{\mathrm{a}}}\right)-\ln \left(\frac{\operatorname{Tur}_{\mathrm{a}}^{\prime}}{\operatorname{Tur}_{\mathrm{b}}^{\prime}}\right)\right)}{\mathrm{t}}$

where "Vi" is the water volume (1) into the containers, "Tur " and "Tur are turbidity values at the beginning and at the end of a time interval respectively, and " $t$ " is the time elapsed in a time interval (i.e. =10 min). "Tur' ${ }_{\mathrm{a}}$ " and "Tur' ${ }_{\mathrm{b}}$ " are also the turbidity values at the beginning and at the end of a time interval but in containers without filter-feeder (i.e. without clam). These latest values are included in Eq. (1) to measure and subtract the natural settling rate of particles from the actual FR (see Cohen et al., 1984 and Riisgård, 2001 for details). To estimate FR in the Clam treatment we used natural settling rate (i.e., $\left.\ln \left(\frac{T_{u r}^{\prime}}{T u r_{b}^{\prime}}\right)\right)$ in containers from the Control treatment, while FR in the Clam-Crab treatment was estimated using natural settling rate in the Crab treatment.

Since this method is based in the decay of particle concentration, a turbidity increment (resuspension) instead of a reduction from the beginning to the end of a time interval implies that the result of the Eq. (1) is negative (e.g. Fabricius et al., 1998; Grizzle et al., 2008). Thus, given that clams can resuspend material enhancing turbidity in the containers mainly by ejection of faeces and pseudofaeces (see Graf and Rosenberg, 1997 ) it is possible to find negative FR values. Besides, natural particle settling occur constantly in the containers without filter-feeder. This highlights one of the main limitations of this method (see Riisgård, 2001) as it can also lead to negative values when this settling is high.

\subsection{Effects of C. angulatus on T. plebeius shell growth and condition index}

To evaluate the effect of $C$. angulatus on shell growth and condition index (CI) of T. plebeius, a second crab Exclusion/Inclusion experiment was carried out between September 2009 and May 2011. Twenty plastic square cages ( $1 \mathrm{~cm}$ mesh and $50 \mathrm{~cm}$ side) were deployed on the intertidal mud flat. Clams (120) were extracted from the mudflat with a shovel, measured in $\mathrm{L}$ and height $(\mathrm{H}$, umbo-ventral axis; precision $\pm 0.01 \mathrm{~mm}$ ) and marked with a plastic number glued to the periostracum surface with cyanoacrylate (superglue) to be identified later. Six marked clams 
between 54 and $66.3 \mathrm{~mm}$ L were set into each cage (reflecting the natural density of clams in the area: 36 clams $\mathrm{m}^{-2}$, Addino et al., 2010). In 10 of the cages, crabs were then added ( 3 males and 2 females respecting natural sex proportion and density following Spivak et al. (1996), inclusion treatment). Crab density into cages was evaluated every 15 days and maintained adding crabs if necessary.

At the end of the experimental time all cages were recovered (except one from exclusion treatment) and all alive and marked clams were collected accounting for a total of 50 clams (nearly 3 clams per cage for all treatments). Final $\mathrm{L}$ and $\mathrm{H}$ (i.e. $\mathrm{L}$ and $\mathrm{H}$ at the end of the experiment) were measured and $\mathrm{Cl}$ was calculated using the dry weight of soft tissue (dried at $80^{\circ} \mathrm{C}$ to constant weight) and the L of clams with the following equation (Clausen and Riisgård, 1996):

$\mathrm{CI}=$ soft tissue $\mathrm{L}-\mathrm{b}$

where $b$ (2.93) is the slope of the regression curve between $\mathrm{L}$ and soft tissue for these clams. The growth increments in $\mathrm{L}$ and $\mathrm{H}$ (i.e. the increase in size ( $\mathrm{L}$ and $\mathrm{H}$ ), hereafter $\mathrm{L}$ increment and $\mathrm{H}$ increment) of each clam were calculated as: final $\mathrm{L}-$ initial $\mathrm{L}$ and final $\mathrm{H}-$ initial $\mathrm{H}$ $(\mathrm{mm})$, respectively. Also their relationship with initial $\mathrm{L}$ and $\mathrm{H}$, respectively, were evaluated by simple regression models. Given that there were no relationships, except for $\mathrm{H}$ increments only in exclusion treatment (see Section 3.3), mean $\mathrm{L}$ increment and mean $\mathrm{H}$ increment were evaluated in further statistical analysis. To perform a more powerful test we looked for differences in mean $\mathrm{Cl}$, L increment and $\mathrm{H}$ increment between replicates (cages) into each treatment by ANOVA analysis (three separate analysis). As differences were not found (see Table 1) data were pooled into each treatment. Thus, we evaluated the null hypothesis of no difference in 1) mean $\mathrm{CI}, 2$ ) mean shell L increment and 3) mean shell $\mathrm{H}$ increment between treatments through $\mathrm{t}_{\mathrm{c}}$ test (3 analysis in total, Zar, 1999).

\section{Results}

\subsection{Displacement of $C$. angulatus in the mudflat}

The number of crabs $\mathrm{h}^{-1}$ crossing around a fixed point showed differences between tidal moments being higher during flooding tide ( $\mathrm{df}=171, \mathrm{~F}=82.2, \mathrm{p}<0.001$; mean $\mathrm{crabs}^{-1}(\mathrm{SD})$ : stable $=2.5$ (3.4), flooding $=18.7(12.2)$, ebbing $=2.9(4.2)$ ). If we extrapolate these $10 \mathrm{~min}$ of observation to the total time period in which tide is flooding (around $5 \mathrm{~h}$ in our study site; M. Addino, pers. obs.) nearly 95 crabs are potentially crossing above the siphon holes of a clam (a fixed point) in this time period.

\subsection{Effect of $C$. angulatus on suspended material and filtration activity of T. plebeius}

Turbidity and Chl $a$ were not different between Crab and Control at time 0 , but they were both higher in Crab treatment 40 min after the beginning (Fig. 2A and B) indicating particle resuspension. Mean shell length (L) was not different between treatments Clam and Clam-Crab $\left(\mathrm{df}=10, \mathrm{t}_{\mathrm{c}}=1.62, \mathrm{p}=0.14\right)$ and there was no relationship between $\mathrm{L}$ and filtration rate (FR) of clams ( $\mathrm{df}=4, \mathrm{~F}=1.54$ and $0.11, \mathrm{p}=0.28$

Table 1

Comparison of $\mathrm{Cl}$ and shell length increment and height increment between replicates into each treatment of the second Exclusion/Inclusion experiment.

\begin{tabular}{lllll}
\hline Treatment & Variable & df & F & p-Value \\
\hline Inclusion & CI & 5 & 2.79 & 0.11 \\
& Shell L increment & 5 & 1.11 & 0.42 \\
\multirow{3}{*}{ Exclusion } & Shell H increment & 5 & 1.14 & 0.41 \\
& CI & 7 & 2.06 & 0.10 \\
& Shell L increment & 7 & 0.72 & 0.66 \\
& Shell H increment & 7 & 1.32 & 0.29 \\
\hline
\end{tabular}
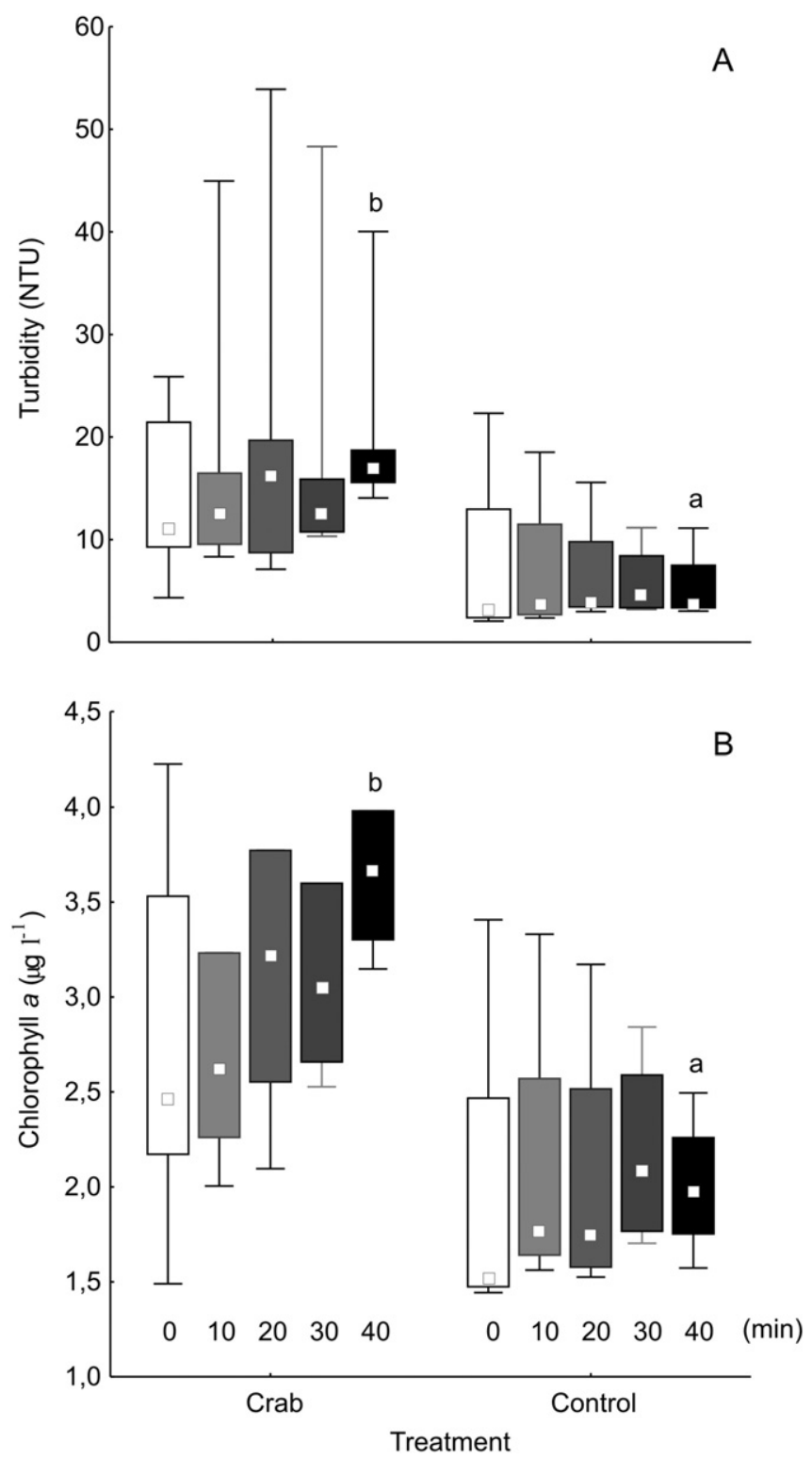

Fig. 2. A) Turbidity and B) Chlorophyll $a$ at different times during the first Exclusion/Inclusion experiment, in treatments $\mathrm{Crab}$ and Control. Middle point denotes median, box limits show 25 and 75\% percentiles and vertical bars minimum and maximum values. Those measurements that showed differences between treatments are indicated with different letters that denote values in ascendant order.

and 0.75; for Clam and Clam-Crab respectively). Mean FR was different between treatments Clam and Clam-Crab being higher in the latter in the last time interval (Fig. 3) showing a positive response to enhanced food supply. Statistical data for turbidity, Chl $a$ and FR are summarized in Table 2.

\subsection{Effects of $C$. angulatus on T. plebeius somatic and shell growth}

Mean condition index $(\mathrm{CI})$ did not show differences between treatments (mean CI (SD) $=0.0039$ (0.0008) and 0.0041 (0.0008) for inclusion and exclusion, respectively, $\mathrm{df}=44, \mathrm{t}_{\mathrm{c}}=-0.91, \mathrm{p}=0.37$ ). There was no relationship between the initial $\mathrm{L}$ and the $\mathrm{L}$ increments of clams in any treatment ( $\mathrm{df}=15$ and $29, \mathrm{~F}=0.3$ and $0.93, \mathrm{p}=0.59$ and 0.35 ; for inclusion and exclusion, respectively). Increments in height $(\mathrm{H})$ showed a negative linear relationship with the initial $\mathrm{H}$ only in exclusion treatment $(\mathrm{df}=15$ and $29, \mathrm{~F}=0.03$ and $12.9, \mathrm{p}=0.86$ and 0.0014; for inclusion and exclusion, respectively, Fig. 4). Also, the mean shell $\mathrm{L}$ increment as well as $\mathrm{H}$ increment was not different 


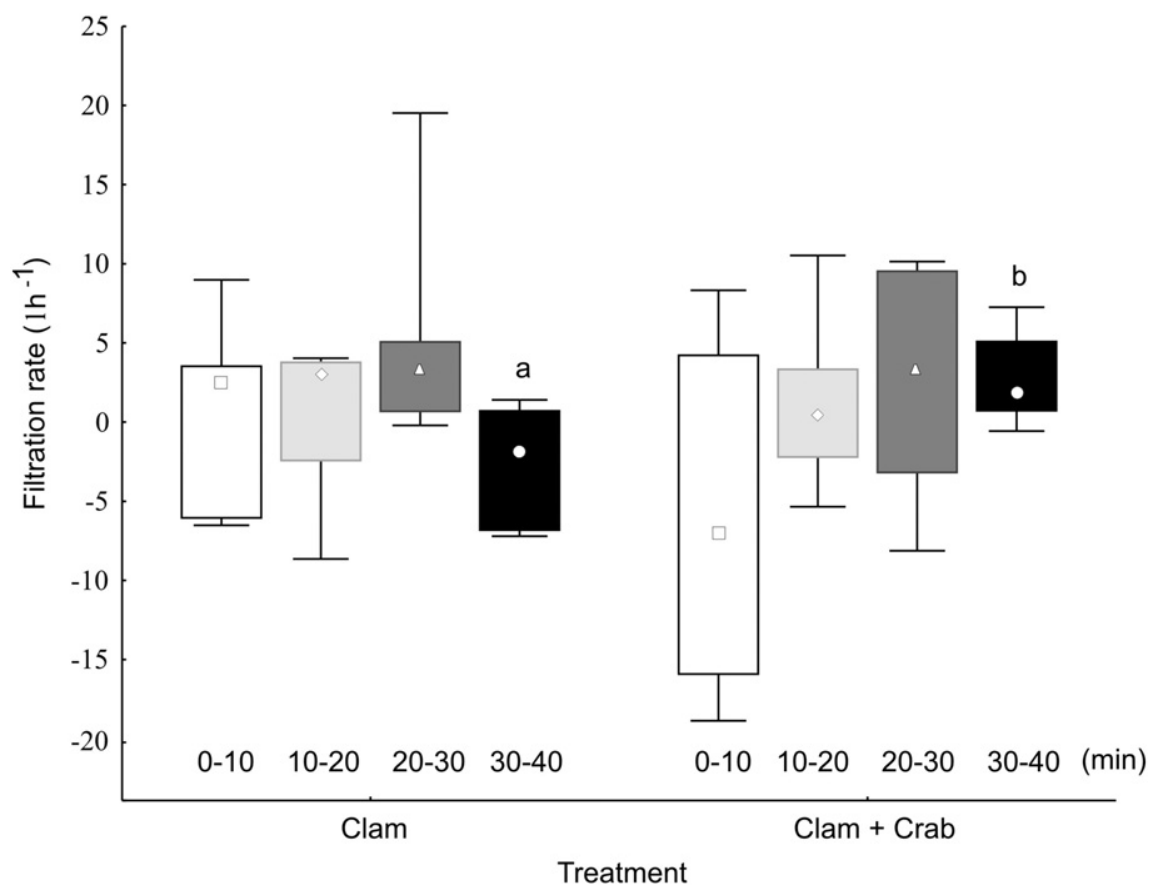

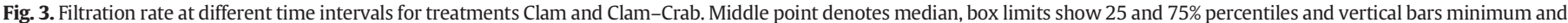
maximum values. Those time intervals that showed differences between treatments are indicated with different letters that denote values in ascendant order.

between treatments ( $\mathrm{L}$ increment: $\mathrm{df}=41.99, \mathrm{t}_{\mathrm{c}}=-1.46, \mathrm{p}=0.15 ; \mathrm{H}$ increment: $\mathrm{df}=42.97, \mathrm{t}_{\mathrm{c}}=-0.66, \mathrm{p}=0.51$ ). However, both shell $\mathrm{L}$ and $\mathrm{H}$ increments showed smaller variances in the inclusion treatment (Levene test, $\mathrm{df}=43, \mathrm{~F}=2.68$ and 6.44, $\mathrm{p}=0.043$ and 0.015 for $\mathrm{L}$ and $\mathrm{H}$ increment respectively; Fig. $5 \mathrm{~A}$ and $\mathrm{B}$ ).

\section{Discussion}

Our results showed that as expected $C$. angulatus present higher migration in the intertidal flat during flooding tide following the tidal water movement. Turbidity and Chl $a$ were enhanced by crabs after 40 min under experimental conditions supporting our suggestions that crabs may act as biodiffusers. Parallel to those changes in the sediment-water interface, FR of clams was higher when crabs were present indicating that there was no negative effect on T. plebeius. Besides, mean clam $\mathrm{CI}$ and mean shell growth increments were not affected by crab presence. However, shell increments both in length as in height presented smaller maximum values in crab inclusions.

The different consumer modes generate different modifications in the sediment-water interface (Nogaro et al., 2009). Bioturbators may also modify resuspension by water turbulence (Davis, 1993; Cadée, 2001) and all together generate different effects on coexisting filter-feeding organism. In previous studies, $C$. angulatus is not commonly considered a bioturbator in the Mar Chiquita coastal lagoon (but see Martinetto et al.

Table 2

Statistical data for turbidity and chlorophyll $a$ comparisons between treatments Crab and Control, and filtration rate between treatments Clam and Clam-Crab.

\begin{tabular}{lllrrl}
\hline Variable & Treatments compared & Time $(\mathrm{min})$ & $\mathrm{df}$ & $\mathrm{t}$-value & $\mathrm{p}$-value \\
\hline Turbidity & Crab-Control & 0 & 8 & 1.08 & 0.31 \\
& & 40 & 8 & 2.88 & $0.02^{*}$ \\
Chl a & Crab-Control & 0 & 8 & 1.19 & 0.27 \\
& & 40 & 8 & 3.79 & $0.005^{*}$ \\
Filtration rate $\left(\mathrm{l} \mathrm{h}^{-1}\right)$ & Clam-Clam-Crab & $0-10$ & 12 & 1.28 & 0.23 \\
& & $10-20$ & 12 & -0.13 & 0.89 \\
& & $20-30$ & 12 & 0.65 & 0.53 \\
& & $30-40$ & 12 & -3.33 & $0.006^{*}$ \\
\hline
\end{tabular}

* Denotes significant differences.
2007 and 2011). Notwithstanding, it is a benthic consumer (Botto et al., $\underline{2005}$ ) which may reach densities of thousands of crabs (Spivak et al., 1994) and may remove superficial sediments (this study) by feeding

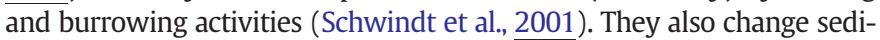
ment parameters such as water content and grain size when construct burrows (Martinetto et al., 2011). Moreover, they show an intense migration along the intertidal related to tides, especially during flooding tide (this study), which may also lead to resuspension of superficial sediment. In fact, in closed systems, we found that this crab enhances particle load into the sediment-water interface as well as Chl $a$ concentration. Hence, our results agree with the general pattern of resuspension attributed to mobile benthic consumer organisms (Murray et al., 2002) and reinforce our suggestions that $C$. angulatus may act as a biodiffuser.

In this context and based in previous generalizations about the interaction between mobile and sessile fauna in soft bottom systems (Rhoads and Young, 1970; Wilson, 1991; Reise, 2002), negative effects of $C$. angulatus on T. plebeius could be expected. Moreover, we evaluated this interaction in closed systems were the changes on sediment and its consequences on clams may be exacerbated. In fact, in the crab treatment turbidity had a range of values almost ten times higher than the natural range (see Section 2.1). However, no negative effects on clams were observed. Parallel to the increment of $\mathrm{Chl} a$ concentration clam FR was higher when crabs were present. As for other filter-feeding estuarine bivalves (e.g. Cerastoderma edule, Tapes decussatus and Mytilus galloprovincialis, Page and Lastra, 2003) resuspended microphytobenthos and phytoplankton comprise the main food sources for this clam (Botto et al., 2005). Thus, the higher Chl a concentration due to biological resuspension by crabs may be considered a positive effect of this mobile species on T. plebeius resources. Given that crabs enhanced turbidity (used with the indirect method to estimate FR, see M\&M Eq. (1)) it would be more probably to find negative values of FR in crab inclusion treatment; however we found the opposite. This positive response of clams FR to increased suspended material and Chl $a$ may be related to the fact that $T$. Plebeius is often found in muddy estuaries, but it also agrees with previous findings in other bivalves like scallops (Placopecten magellanicus, Cranford et al., 1998), oysters (Pinctada margaritifera, Pouvreau et al., 2000) and mussels (Mytilus edulis, Newell et al., 2001). Additionally, it adds to the hypothesis that 


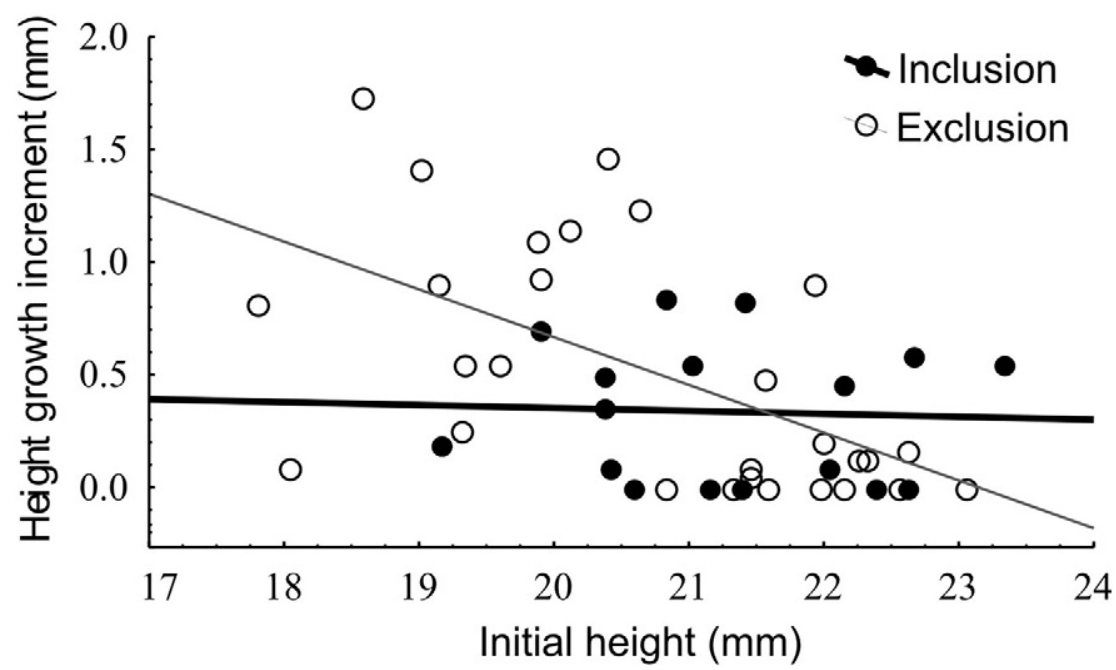

Fig. 4. Relationship between initial height and height growth increment of clams in the second Exclusion/Inclusion experiment.
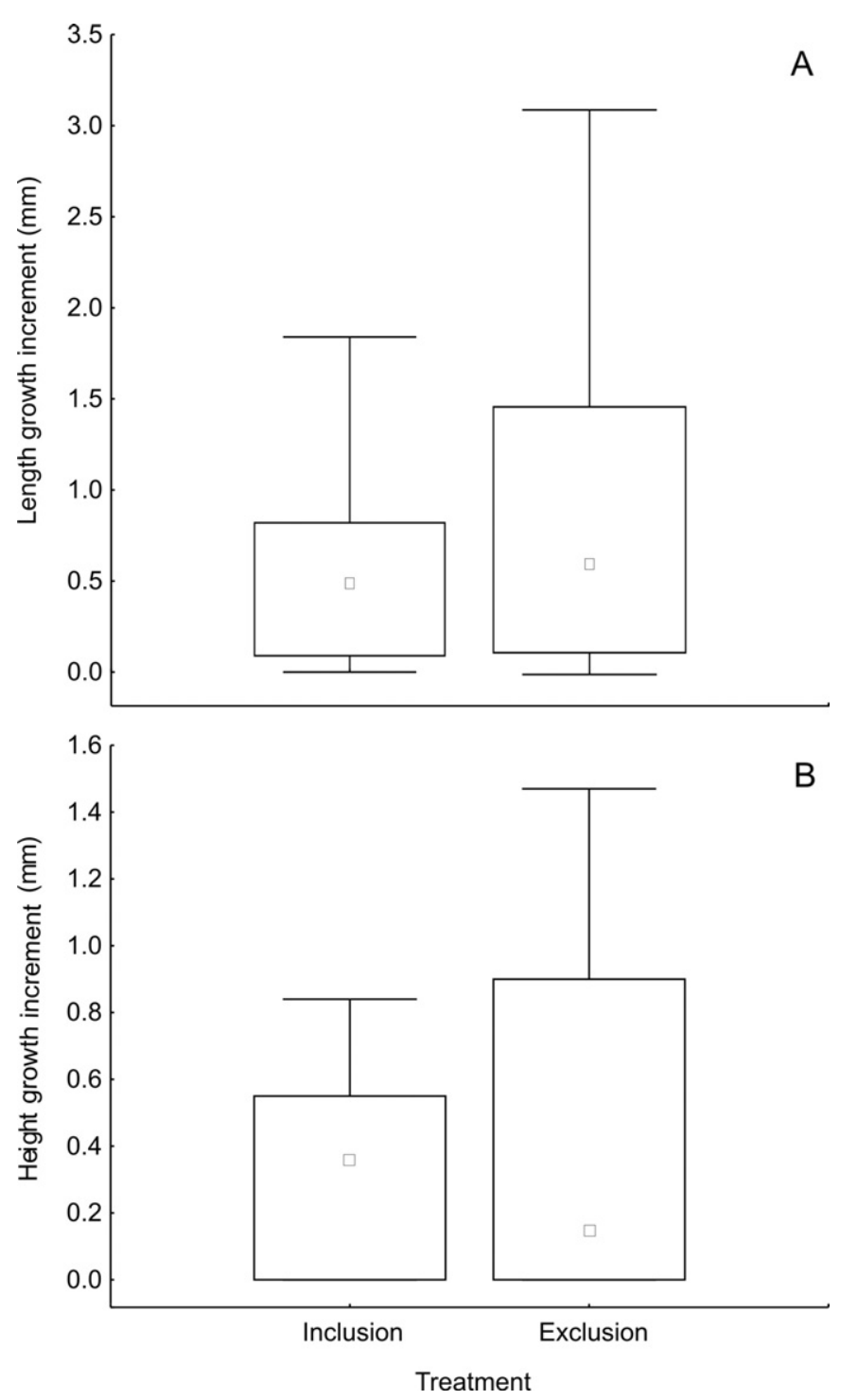

Fig. 5. Shell growth increments in A) length and B) height in the second Exclusion/Inclusion experiment. Middle point denotes median, box limits show 25 and $75 \%$ percentiles and vertical bars minimum and maximum values. filtration activity is not physiologically regulated but it is determined by the physical capacity of filtration apparatus and the environmental prevalent food concentration (Hawkins et al., 1996; Jørgensen, 1996). Nevertheless, enhanced food acquisition may have costs due to pseudofaeces production and thus, a negative impact (e.g. Bayne et al., 1987; Ellis et al., 2002). Therefore, the lack of knowledge about the costs associated to the higher FR of T. plebeius makes it difficult to conclude if this effect is really positive for this clam. However, even when turbidity generated by crabs is almost ten times greater than in the natural conditions (this study); there was no negative effect on clams, such as stuck of filtration apparatus which is commonly predicted (Rhoads and Young, 1970; Wilson, 1991) for this kind of interaction.

Negative effects that mobile species generate on sessile organisms can be mediated by direct contact (e.g. Lomovasky et al., 2006) or more frequently by indirect mechanisms (e.g. Murphy, 1985; Nakaoka, 2000; Mermillod-Blondin and Rosenberg, 2006). In the case of $T$. plebeius and $C$. angulatus we suggested that crabs negatively affect the clam's growth by indirect mechanisms that change clams' behaviour. However, in our study the second inclusion/exclusion field experiment showed no effect of $C$. angulatus on mean clams $\mathrm{CI}$ neither on mean clam shell growth increments. Nevertheless, only for clams with initial height between 17.5 and $20.5 \mathrm{~mm}$ the height growth increment was smaller in inclusion treatment. That is, in smallest clams the height increment was diminished. Besides, the maximum values of shell increment, both in length and in height were smaller in inclusion treatment which leads to smaller variances. This means that when crabs are present, shell growth may be partially limited leading to smaller maximum clam sizes. This result may also be explained by changes in clam behaviour (e.g. escape behaviour, feeding interruption) and consequent energy cost. However, on average this effect is negligible in the case of the interaction between $C$. angulatus and T. plebeius.

Filtration capacity is adapted to the prevalent natural food concentration in the environment and thus, this trait maximizes resource use allowing bivalves to almost completely exploit their growth and/or reproductive potential (Jørgensen, 1996). We found that the crabs can increase clams' resources by resuspension under experimental conditions without generating negative effects on clams such as clogging of filtration apparatus. In addition, we found no effect of crab presence on clam's growth. Thus, our findings show that clams can exploit the increased food availability (i.e., Chl $a$ ) generated by biological resuspension and are also adapted to the disturbance that the crabs can make over siphon holes. In conclusion, contrary to the generalized outcome proposed for this kind of interaction, in this case crabs do not have a negative effect on $T$. plebeius. 


\section{Acknowledgements}

We thank Maria Cielo Bazterrica and Guillermo Panisse for the field assistance and Macarena Valiñas for the valuable comments on the manuscript. This project was supported by grants from FONDECyT (PICT No. 2007-01272) and CONICET (Argentina; PIP No. 112-20110100863). This is part of M. Addinos Doctoral thesis. [SW]

\section{References}

Addino, M., 2014. Efecto de características físicas del ambiente e interacciones biológicas en los patrones de distribución e historia de vida de la almeja navaja Tagelus plebeius Tesis de Doctorado Universidad Nac. De Mar del Plata, Facultad de Cs. Exactas y Naturales (168 pp.)

Addino, M., Lomovasky, B.J., Cremonte, F., Iribarne, O., 2010. Infection by gymnophallid metacercariae enhances predation mortality of SW Atlantic stout razor clam Tagelus plebeius. J. Sea Res. 63, 102-107.

Alvarez, M.F., 2013. Heterogeneidad espacial y fuerzas de interacción en tramas tróficas de ambientes estuariales costeros Tesis doctoral Universidad Nac. de Mar del Plata, Argentina.

Bayne, B.L., Hawkins, A.J.S., Navarro, E., 1987. Feeding and digestion by the mussel Mytilus edulis L. (Bivalvia: Mollusca) in mixtures of silt and algal cells at low concentrations. J. Exp. Mar. Biol. Ecol. 111, 1-22.

Boschi, E.E., 1964. Los crustáceos decápodos Brachyura del Litoral Bonaerense. Bol. Inst. Biol. Mar. Mar del Plata 6, 1-76.

Botto, F., Valiela, I., Iribarne, O., Martinetto, P., Alberti, J., 2005. Impact of burrowing crabs on $\mathrm{C}$ and $\mathrm{N}$ sources, control, and transformations in sediments and food webs of SW Atlantic estuaries. Mar. Ecol. Prog. Ser. 293, 155-164.

Boudreau, B.P., 1997. A one-dimensional model for bed-boundary layer particle exchange. J. Mar. Syst. 11, 279-303.

Bruschetti, M., Luppi, T., Fanjul, E., Rosenthal, A., Iribarne, O., 2008. Grazing effect of the invasive reef-forming polychaete Ficopomatus enigmaticus (Fauvel) on phytoplankton biomass in a SW Atlantic coastal lagoon. J. Exp. Mar. Biol. Ecol. 354, 212-219.

Cadée, G.C., 2001. Sediment dynamics by bioturbating organisms. Ecol. Stud. 151, 127-148.

Clausen, I., Riisgård, H., 1996. Growth, filtration and respiration in the mussel Mytilus edulis: no evidence for physiological regulation of the filter-pump to nutritiona needs. Mar. Ecol. Prog. Ser. 141, 37-45.

Cohen, R.R.H., Dresler, P.V., Phillips, E.J.P., Cory, R.L., 1984. The effect of the Asiatic clam, Corbicula fluminea, on phytoplankton of the Potomac River, Maryland. Limnol. Oceanogr. 29, 170-180.

Cranford, P.J., Emerson, C.W., Hargrave, B.T., Milligan, T.G., 1998. In situ feeding and absorption responses of sea scallops Placopecten magellanicus (Gmelin) to storminduced changes in the quantity and composition of the seston. J. Exp. Mar. Biol. Ecol. 219, 45-70.

Davis, R., 1993. The role of bioturbation in sediment resuspension and its interaction with physical shearing. J. Exp. Mar. Biol. Ecol. 171, 187-200.

Ellis, J. Cummings, V. Hewitt, J., Thrush, S., Norkko, A., 2002. Determining effects of suspended sediment on condition of a suspension feeding bivalve (Atrina zelandica): results of a survey, a laboratory experiment and a field transplant experiment. J. Exp. Mar. Biol. Ecol. 267, 147-174.

Fabricius, K., Yahel, G., Genin, A., 1998. In situ depletion of phytoplankton by an azooxanthellate soft coral. Limnol. Oceanogr. 43, 354-356.

Fasano, J.L., Hernández, M.A., Isla, F.I., Schnack, J.E., 1982. Aspectos ambientales y evolutivos de la Laguna Mar Chiquita (provincia de Buenos Aires, Argentina). Oceanol. Acta 285-292.

François, F., Gerino, M., Stora, G., Durbec, J., Poggiale, J., 2002. Functional approach to sediment reworking by gallery-forming macrobenthic organisms: modeling and application with the polychaete Nereis diversicolor. Mar. Ecol. Prog. Ser. 229, 127-136.

Graf, G., Rosenberg, R., 1997. Bioresuspension and biodeposition: a review. J. Mar. Syst. 11, 269-278.

Grizzle, R.E., Greene, J.K., Coen, L.D., 2008. Seston removal by natural and constructed intertidal eastern oyster (Crassostrea virginica) reefs: a comparison with previous laboratory studies, and the value of in situ methods. Estuar. Coasts 31, 1208-1220.

Gutiérrez, J., Iribarne, O.0., 2004. Conditional responses of organisms to habitat structure: an example from intertidal mudflats. Oecologia 139, 572-582.

Hawkins, A.J., Smith, R.F., Bayne, B.L., Héral, M., 1996. Novel observations underlying the fast growth of suspension-feeding shellfish in turbid environments: Mytilus edulis. Mar. Ecol. Prog. Ser. 131, 179-190.

Herman, P., Middelburg, J., Van de Koppel, J., Heip, C., 1999. Ecology of estuarine macrobenthos. Adv. Ecol. Res. 29, 195-240.

Holland, A.F., Dean, J.M., 1977. The biology of the stout razor clam Tagelus plebeius: I. Animal-sediment relationships, feeding mechanism, and community biology. Chesap. Sci. 18, 58-66.

Isla, F.I., 1997. Seasonal behavior of Mar Chiquita tidal inlet in relation to adjacent beaches, Argentina. J. Coast. Res. 13, 1221-1232.

Isla, F.I., Garrido, E.S., 2001. Evolución geológica de la Laguna de Mar Chiquita. In: Iribarne, O. (Ed.), Reserva de biosfera mar Chiquita: características físicas, biológicas y ecológicas. Editorial Martín, Mar del Plata, Argentina, pp. 19-31.

Jørgensen, C., 1996. Bivalve filter feeding revisited. Mar. Ecol. Prog. Ser. 142, 287-302.

Leal, J.H., 2002. Bivalvia. In: Carpenter, K.E. (Ed.), The Living Marine Resources of the Western Central Atlantic. I: Introduction, Mollusks, Crustaceans, Hagfishes, Sharks,
Batoid Fishes and ChimaerasFAO Identification Guide for Fishery Purposes. FAO, Rome, pp. 25-98.

Lomovasky, B., Casariego, A., Brey, T., Iribarne, O., 2006. The effect of the SW Atlantic burrowing crab Chasmagnathus granulatus on the intertidal razor clam Tagelus plebeius. J. Exp. Mar. Biol. Ecol. 337, 19-29.

Martinetto, P., Valiñas, M., Palomo, G., Iribarne, O., 2007. Negative interactions between two SW Atlantic intertidal crabs in soft-bottoms habitats. Mar. Biol. 151, 1479-1490.

Martinetto, P., Palomo, G., Bruschetti, M., Iribarne, O., 2011. Similar effects on sediment structure and infaunal community of two competitive intertidal soft-bottom burrowing crab species. J. Mar. Biol. Assoc. U. K. 91, 1-9.

Mermillod-Blondin, F., Rosenberg, R., 2006. Ecosystem engineering: the impact of bioturbation on biogeochemical processes in marine and freshwater benthic habitats. Aquat. Sci. 68, 434-442.

Michaud, E., Desrosiers, G., Mermillodblondin, F., Sundby, B., Stora, G., 2006. The functional group approach to bioturbation: II. The effects of the Macoma balthica community on fluxes of nutrients and dissolved organic carbon across the sediment-water interface. J. Exp. Mar. Biol. Ecol. 337, 178-189.

Murphy, R.C., 1985. Factors affecting the distribution of the introduced bivalve, Mercenaria mercenaria, in a California lagoon - the importance of bioturbation. J. Mar. Res. 43, 673-692.

Murray, J.M., Meadows, A., Meadows, P.S., 2002. Biogeomorphological implications of microscale interactions between sediment geotechnics and marine benthos: a review. Geomorphology 47, 15-30.

Nakaoka, M., 2000. Nonlethal effects of predators on prey populations: predatormediated change in bivalve growth. Ecology 81, 1031-1045.

Newell, C.R., Wildish, D.J., MacDonald, B.A., 2001. The effects of velocity and seston concentration on the exhalant siphon area, valve gape and filtration rate of the mussel Mytilus edulis. J. Exp. Mar. Biol. Ecol. 262, 91-111.

Nogaro, G., Mermillod-Blondin, F., Valett, M.H., François-Carcaillet, F., Gaudet, J.P., Lafont, M., Gibert, J., 2009. Ecosystem engineering at the sediment-water interface: bioturbation and consumer-substrate interaction. Oecologia 161, 125-138.

Olivier, S.R., Escofet, A., Penchaszadeh, P., Orensanz, J.M., 1972. Estudios ecológicos de la región estuarial de Mar Chiquita. II. Relaciones tróficas interespecíficas. Anal. Soc. Cient. Argent. 194, 89-104.

Page, H.M., Lastra, M., 2003. Diet of intertidal bivalves in the Ria de Arosa (NW Spain): evidence from stable C and N isotope analysis. Mar. Biol. 143, 519-532.

Pillay, D., Branch, G., Forbes, A., 2007. The influence of bioturbation by the sandprawn Callianassa kraussi on feeding and survival of the bivalve Eumarcia paupercula and the gastropod Nassarius kraussianus. J. Exp. Mar. Biol. Ecol. 344, 1-9.

Posey, M., 1987. Influence of relative mobilities on the composition of benthic communities. Mar. Ecol. Prog. Ser. 39, 99-104.

Pouvreau, S., Bodoy, A., Buestel, D., 2000. In situ suspension feeding behaviour of the pearl oyster, Pinctada margaritifera: combined effects of body size and weather-related seston composition. Aquaculture 181, 91-113.

Reise, K., 2002. Sediment mediated species interactions in coastal waters. J. Sea Res. 48, 127-141.

Reta, R., Martos, P., Perillo, G.M.E., Piccolo, M.C., Ferrante, A., 2001. Características hidrográficas del estuario de la Laguna de Mar Chiquita. In: Iribarne, O. (Ed.), Reserva de biosfera Mar Chiquita: características físicas, biológicas y ecológicas. Editorial Martín, Mar del Plata, Argentina, pp. 31-52.

Rhoads, D.C., Young, D.K., 1970. The influence of deposit-feeding organisms on sediment stability and community trophic structure. J. Mar. Res. 28, 150-178.

Riisgård, H., 2001. On measurement of filtration rate in bivalves - the stony road to reliable data: review and interpretation. Mar. Ecol. Prog. Ser. 211, 275-291.

Rosenberg, R., 2001. Marine benthic faunal successional stages and related sedimentary activity. Sci. Mar. 65, 107-119.

Scarabino, V., 1977. Moluscos del Golfo San Matías (Provincia de Río Negro, República Argentina). Inventario y claves para su identificación. Comunicaciones de la Sociedad Malacológica de Uruguay 4, 177-285.

Schwindt, E., Bortolus, A., Iribarne, O., 2001. Invasion of a reef-builder polychaete: direct and indirect impacts on the native benthic community structure. Biol. Invasions 3 , 137-149.

Seitz, R.D., Lipcius, R.N., Olmstead, N.H., Seebo, M.S., Lambert, D.M. 2006. Influence of shallow-water habitats and shoreline development on abundance, biomass, and diversity of benthic prey and predators in Chesapeake Bay. Mar. Ecol. Prog. Ser. 326, 11-27.

Snelgrove, P.V.R., Butman, C.A., 1994. Animal-sediment relationships revisited: cause versus effect. Oceanogr. Mar. Biol. Annu. Rev. 32, 111-177.

Spivak, E., 1997. Cangrejos estuariales del Atlántico sudoccidental $\left(25^{\circ}-41^{\circ} \mathrm{S}\right)$ (Crustacea: Decapoda: Brachyura). Investig. Mar. Valparaiso 25, 105-120.

Spivak, E., Anger, K., Luppi, T., Bas, C., Ismael, D., 1994. Distribution and habitat preferences of two grapsid crab species in Mar Chiquita Lagoon (Province of Bueno Aires, Argentina). Helgoländer Meeresun. 48, 59-78.

Spivak, E., Anger, K., Bas, C., Luppi, T., Ismael, D., 1996. Size structure, sex ratio and breeding season in two intertidal grapsid crab species from Mar Chiquita lagoon, Argentina. Nerít. Curitiva 10, 7-26.

Widdows, J., Brinsley, M., 2002. Impact of biotic and abiotic processes on sediment dynamics and the consequences to the structure and functioning of the intertidal zone. J. Sea Res. 48, 143-156.

Wilson, W.H., 1991. Competition and predation in marine soft-sediment communities. Annu. Rev. Ecol. Syst. 21, 221-241.

Zar, J.H., 1999. Biostatistical Analysis. fourth ed. Prentice-Hall, Inc., Englewood Cliffs, NJ (718 pp.). 